Anna PROTASIEWICZ, MA

Faculty of Economics and Finance, University of Bialystok

e-mail: a.protasiewicz@uwb.edu.pl

ORCID: 0000-0003-2256-8273

DOI: $10.15290 /$ oes.2020.02.100.06

\title{
INNOVATIVENESS OF ENTERPRISES IN POLAND AND THEIR CAPACITY TO ABSORB INNOVATION ${ }^{1}$
}

\begin{abstract}
Summary
Purpose - The purpose of the article is to analyse the conditions of enterprises and their capacity to absorb innovation, and more specifically the impact of the current level of innovation of entities operating in the Polish economy.

Research method - The research was based on the analysis of individual innovation indicators of the Polish economy, with particular emphasis on the factors related to R\&D (GUS data, European Innovation Scoreboard, Global Innovation Index, The Global Competitiveness Report).

Results - Analyses indicate that the main barriers to the development and implementation of innovative solutions by enterprises result primarily from their internal conditions, as the ability to absorb innovations is related to the knowledge and skills already possessed by the enterprise. In the case of Polish enterprises, their level of innovation is still insufficient to be able to fully adapt new solutions from external sources.

Originality / value / implications / recommendations - The value of the article is its approach according to which the innovativeness of entities is not only the result of innovation diffusion, but the capacity to absorb innovation is related to the pre-existing level of innovation.
\end{abstract}

Keywords: innovation, diffusion of innovation, innovative activity, ability to absorb innovation

JEL Classification: $\mathrm{O} 33$

\section{Introduction}

Innovativeness of an organisation signifies its capacity of absorption, that is a constant search, implementation and diffusion of innovations. Nowadays, the capacity to implement innovation is treated as one of the most important characteristics of a business entity, which has a great influence on its competitiveness and thus on its market position. It seems that the key element in that respect is the application of newly developed ideas and the dynamics of implemented changes in

${ }^{1}$ Article received on 02 March 2020, accepted on 02 April 2020. 
the process of commercialisation of innovations [Barańska-Fischer, Blażlak, 2016, p. 10].

The purpose of this article is to analyse the conditions determining the capacity of businesses to absorb innovations, and in particular the impact of the pre-existing level of innovativeness of companies operating in the Polish market. The analysis of individual innovation indicators shall refer to the period 2015-2019, with specific emphasis on the factors related to outlays for R\&D.

\section{Innovativeness and the process of innovation diffusion}

Innovation is a new solution in any field of activity, the implementation of which is related to achieving positive economic benefits, for example through an improved satisfaction of needs and/or more effective use of resources [Niedzielski, Rychlik, 2007, p. 23]. According to the definition presented in the Oslo Manual, where innovation is a new or improved product or process (or their combination) that differs significantly from the firm's previous products or processes and that has been made available to potential users (product) or brought into use by the unit (process) [Oslo Manual..., 2018, p. 32]. Alternatively, business innovation is a new or improved business product or process (or their combination), which differs significantly from the entity's previous business products or processes, that has been introduced into the market or has been brought into use by the firm. A business process innovation is a new or re-engineered business process for one or more business functions that differs significantly from the firm's previous processes and has been brought into use by the firm. [Oslo Manual..., 2018, pp. 68-69]. Those definitions also include the diffusion of innovation.

Models of innovation processes can be divided into closed and open types. Up until the second half of the $20^{\text {th }}$ century, there was a dominating traditional (closed) approach, based on own resources, which are strictly protected against competition. Such an approach required significant outlays for research and development activities, therefore innovation was mostly available for large and financially stable entities. At the beginning of the $21^{\text {st }}$ century, there was a growing importance in obtaining and using external knowledge, which influenced the model of open innovation. It was a combination of the internal (in-house) knowledge of a company and external knowledge. Such forms of feedback relations involved greater roles of cooperation between various organisations [Ciborowski, 2012, p. 58]. In the case of open innovation, the most important element is not only to use a company's internal research, but to share knowledge and acquire solutions from other organisations, which also means allowing in-house not utilised solutions for use by other entities (sale of a licence, spin-off entities) [Chesbrough, 2002, p. 18].

Each innovation has its source, that is a place where a new idea or phenomenon has been developed contributing to the creation of such innovation. That is related both to the external environment, whose constant analysis allows for introducing changes and adjusting them to the needs of the surrounding environment and is 
related to the company itself by analysing its available resources. Among the external sources of innovation, there are domestic sources (universities, schools supervised be respective ministries, schools of vocational education, development centres, research institutes of the Polish Academy of Sciences) and foreign sources (foreign R\&D units, transfer of knowledge, purchase of licences and/or know-how, exchange of experience, staff trainings, joint research projects, import of equipment) [Karpińska et al., 2017, p. 18].

Innovation and related processes are accompanied by innovation absorption and diffusion. Absorption of innovation is the general capacity to uptake and adopt innovation. The diffusion of innovation signifies the process of spreading new products or processes, whose beginning has been identified with a date of the initial innovation, while its end is usually difficult to specify, since after diffusion on the national scale, the international spreading of innovation begins [Pomykalski, 2001, p. 41]. Adoption or rejection of an innovation may lead, for example, to changes which affect the economic structure.

E. M. Rogers, the author of the diffusion of innovation theory, defines this idea as the process of innovation communication in the social system [Rogers, 2003, p. 11]. Among the fundamental elements of diffusion there are the following: innovation and its features, communication channels, time necessary for adaptation, and social environment (collection of interrelated entities in a given system) [Kasperkiewicz, 2009, pp. 22-24]. Diffusion is the first successful application of a certain invention when it loses its local character, and there is an expansion of its production area based on the usage of its properties. Therefore, it is related to the innovation process and commercialisation of innovation. It is also its continuation and the prolongation of the innovation process [Gwarda-Gruszczyńska, 2017, p. 386]. Thus, diffusion may be interpreted as the spreading of innovation among manufacturers or the popularisation of a new product used among consumers. Therefore, in these circumstances we do not have an aspect of acquiring and using technological solutions as a consequence of an agreement made between entities, and only of the effect which is the final solution (product) [Firszt, 2012, p. 20].

By analysing the method of spreading innovation, it is possible to distinguish two levels of its absorption, i.e. in a passive and an active form. Passive absorption refers to a capacity of a region (an area) to accept a positive response from target markets (also investors) to undertake actions. Active absorption means a capacity to create and develop the consequences of such activities by using and strengthening the synergy effect [Spychalska-Wojtkiewicz, 2017, p. 41]. The synergy effect is the main purpose of innovation diffusion, i.e. a process where the entity accepting a certain solution can use the adopted solution for the further enhancement of innovation. 


\section{Levels of innovation of Polish businesses}

According to the definition provided by the Office of Statistics Poland (GUS), a company which is innovatively active during a period in question has introduced at least one innovative product or business process or has undertaken at least one innovation project which has been stopped or abandoned during the period in question (unsuccessful) or has not been completed by the end of the period (i.e. it is being continued). On the other hand, an innovative company in the field of innovative products and business processes is a company which during the period in question has introduced to the market at least one innovation related to products or business processes (a new or improved product or improved business process) [Driałalność innowacyjna..., 2019, p. 29].

Innovative activities include all developmental, financial and commercial actions undertaken by a company, whose goal is innovation [Oslo Manual..., 2018, p. 68]. Innovation activities also include $R \& D$ which is not directly focused on creating a specific innovation. Innovation activity of a company may be: successfully completed with an implementation of innovation (however, it does not have to be related to a commercial success); on-going or in progress, which has not been yet implemented; or abandoned prior to the implementation of innovation [Driałalnosić innowacyjna..., 2019, p. 101]. Research and Development (R\&D) includes any creative work undertaken in an systematic way with the goal of increasing the resources of knowledge, including knowledge about humankind, culture and society, in order to create new applications for the existing knowledge; as such it is novel, creative, uncertain, systematic, and also transferable and/or reproducible [Podrecznik Frascati $2015 \ldots, 2018$, p. 47].

Among the indicators used to measure the innovation of economies, there exist intermediate indicators referring to the outlays and results related to $R \& D$ (for example, patents, technological intensity) and direct indicators of innovation.

During the period 2016-2018, 26.1\% of manufacturing companies and $21 \%$ of service companies exhibited innovation activities, in comparison to the years 20152017, where the percentages respectively amounted to $20.2 \%$ and $11.9 \%$ [Driałalność innowacyjna..., 2019, p. 29; Driałalność innowacyjna..., 2018, p. 21]². Outlays for innovation activities (table 1) with reference to manufacturing companies decreased in the years 2015-2018 from PLN 31,094.1 million to PLN 23,388.7 million. However, expenditure of service companies, after the drop in 2016 are currently on a stable level of ca. PLN 131000 million.

\footnotetext{
2It should be noticed that, from the methodological point of view, the data of 2018 is partially different from the data presented in the previous year, which results from the implementation of a new methodology of studies on innovation in the European Union, according to the fourth revised edition of the Oslo Manual [2018] published in 2018. The main change is the introduction of a new category of innovation, i.e. innovation of business processes, and resignation from the previously studied processorganisation- and marketing-related innovations.
} 
TABLE 1

Outlays for innovation in Poland from 2015 to 2018 (in PLN mln)

\begin{tabular}{|l|c|c|c|c|}
\hline & $\mathbf{2 0 1 5}$ & $\mathbf{2 0 1 6}$ & $\mathbf{2 0 1 7}$ & $\mathbf{2 0 1 8}$ \\
\hline Manufacturing companies & 31094.1 & 28304.7 & 28023.5 & 23388.7 \\
\hline Service companies & 12640.9 & 10706.2 & 13142.2 & 13094.8 \\
\hline
\end{tabular}

Source: [Driatalność innowacyjna ..., 2016, 2017, 2018, 2019].

One of the main indicators used to measure the innovation performance of EU economies is the European Innovation Scoreboard. It includes four major categories of indicators and ten dimensions of innovation, which jointly translate into 27 parameters, including the following [European Innovation..., 2019, pp. 3-4]:

- framework conditions - the main innovation drivers which are beyond the company's influence: human resources, attractive research systems and innovation-friendly environment:

- investments - public and private investment in research and innovation, including finance and support, and own-resource investment;

- innovation activities - innovation efforts at the company level: innovators, linkages, and intellectual assets;

- impacts - illustrate how company's innovation activities impact employment and sales volume.

The subtotal innovation indicator divides the member states into four performance groups: innovation leaders, strong innovators, moderate innovators, and modest innovators.

The results for 2019 are presented in chart 1, where Poland's ranking is below the EU average (next to Croatia, the Czech Republic, Greece, Hungary, Italy, Lithuania, Latvia, Malta, Portugal, Slovakia, Slovenia and Spain) and is classified as a Moderate Innovator. Nations who are among the Innovation Leaders are: Denmark, Finland, the Netherlands and Sweden, whose innovation performance is much above the EU average. Performance that is weaker than that of Poland can be observed in Bulgaria and Romania (Modest Innovators), as well as Hungary which is in the group of Moderate Innovators.

An analysis of individual components of the indicator allows us to conclude that the problem is due to a low level of innovation in micro-companies and SME's, and the inclination of those companies (who invest in innovation) to collaborate with other companies. The critical issue also concerns research (low standard represented by $\mathrm{PhD}$ dissertations by foreign students and international publications) [European Innovation..., 2019, p. 63]. The growth rate of individual factors is still insufficient in comparison to the increase of the EU average.

A further important indicator is the Global Innovation Index published by Cornell University in cooperation with, among other entities, the World Intellectual Property Organization (WIPO), a specialised agency of the United Nations. The Global Innovation Index is calculated as an average of factors describing the environment which facilitate innovation, as well as the performance indicators for 
innovation. On the one hand, it includes: institutions, human capital, research, infrastructure, market diversification and diversification of the enterprises sector; on the other hand, it studies the effects of innovation activities: development of new knowledge and creative results [Rószkiewicz, 2015, p. 231]. In 2019 (similarly to the previous year), Poland was ranked 39th among 129 countries, scoring 41.31 points (out of 100). This result can be attributed to Poland's high results in the areas of students' PISA results ( $17^{\text {th }}$ position), export of creative goods $\left(12^{\text {th }}\right)$, trade, competitiveness and market size $\left(21^{\text {st }}\right)$ and payments for intellectual property $\left(32^{\text {nd }}\right)$. The elements of the indicator which concern knowledge absorption (apart from the aforementioned payments for intellectual property or research talents) are below the average: import of ICT services $\left(56^{\text {th }}\right)$, or the impact of foreign direct investment (56 $\left.{ }^{\text {th }}\right)$ [The Global Innovation Index..., 2019, p. 311].

CHART 1

\section{Performance of EU Member States' innovation systems according} to the subtotal indicator of the European Innovation Scoreboard 2019*

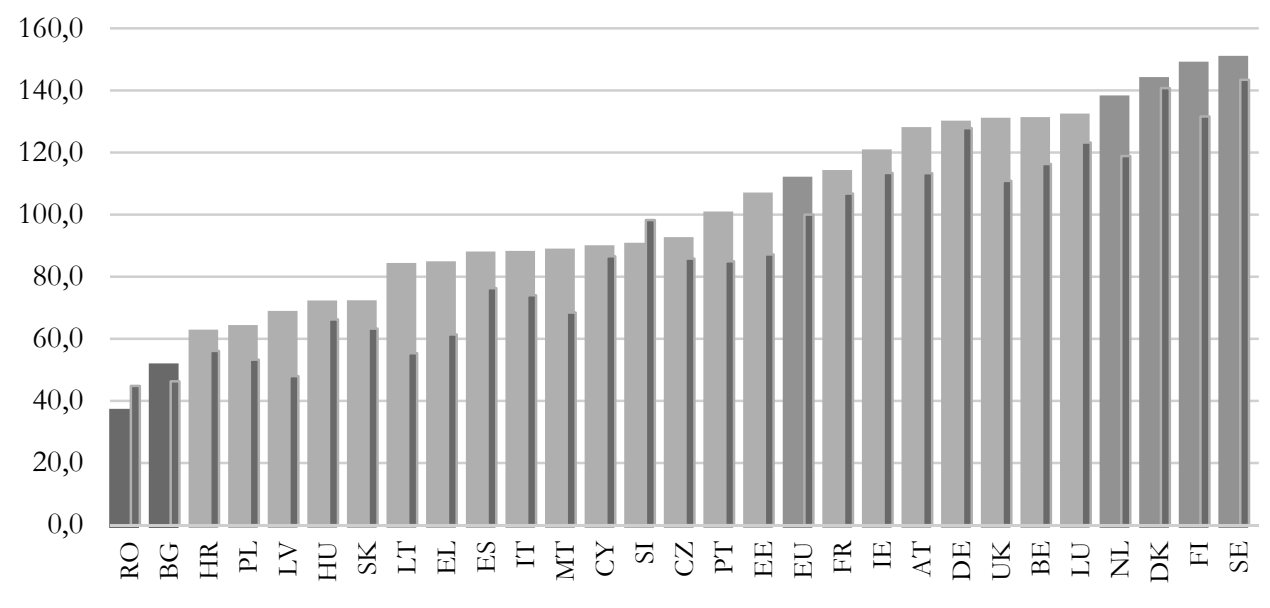

- 2018 to $2011 \quad$ = 2011

* The graph shows the results of the EU member states in 2018 in comparison to the EU results in 2011. The narrow dark coloured bars represent the results of the EU member states in 2011 in comparison to the EU results in 2011. The same method of measurement was applied for all years. Dashed lines indicate the threshold values between the groups in 2018, by comparing the results of the EU member states in 2018 with the EU results in 2018.

Source: [European Innovation..., 2019, p. 13].

The last quoted ranking is The Global Competitiveness Report [2019], prepared by the World Economic Forum. It includes 12 sub-indicators, which concern the following categories: state institutions, infrastructure, the macroeconomic framework, public health and primary education, higher education and training, efficient goods market, 
efficient labour market, developed financial market, ability to harness existing technology, market size, business sophistication levels and innovation. In the last category, Poland has been ranked $37^{\text {th }}$, with a high indicator of macroeconomic stability, infrastructure or the market size. In view of the subject matter hereof, it is necessary to pay attention to the indicators describing the innovative economy, and in particular that of innovation absorption. Poland's capacity to innovate was ranked 39th among 129 economies, with specific positions related to commercialisation $\left(43^{\text {rd }}\right)$ and interaction and diversity $\left(74^{\text {th }}\right)$. A satisfactory result was awarded to research and development (31 st out of 129 countries) [The Global Competitiveness ..., 2019, p. 469].

\section{Innovation existing at recipient companies as a factor significant for innovation diffusion}

The increase of the country's technology level is not the same as increasing its capacity to create globally innovative solutions. Despite a direct impact of the transfer on innovativeness, there is a indirect impact on the economy. In such a context, a particularly important aspect is to accelerate the rate of increasing absorption capacities, so that they can compensate the impact of the "advantage of being backward" resulting from the diminishing technology gap [Firszt et al., 2013, pp. 15$16]$.

On the one hand, in less developed countries the technology gap may increase not as a result of the innovation, but due to the insufficiently fast absorption of new solutions. The capacity to absorb new technologies is negatively correlated with the level of the technology gap. A technology gap also becomes a stimulus for weaker economies to level the gap and chase the leaders. The aforementioned advantage results from the possibility to copy previously discovered technologies, incurring lower costs in comparison to their development. Moreover, the bigger the gap, the larger the spectrum to copy solutions is, which results with a rapid development of imitative economies. According to the Gerschenkron's hypothesis, "potentially, the most effective closing of the technology gap is not symmetrical or sequential, but it is rather a step change which ultimately leads to the reverse of comparative advantages" [Kubielas, 2009, p. 161, p. 241].

The capacity to absorb innovation both from other domestic entities and from abroad is of fundamental importance in the case of economies which are on the lower level of development. It results from their low capacity to create their own innovation, which could permanently increase their capacity to compete. One of the results of innovation diffusion is the innovation effect: on the one hand, production of technologically advanced goods, followed by the elaboration of the capacity to create them [Firszt, 2012, pp. 45-46]. Apart from creating new solutions, the capacity to absorb innovation is treated as one of the main factors of social and economic growth [Niedzielski, Rychlik, 2007, p. 73]. In less developed economies, the process of innovation absorption takes three stages: acquisition, assimilation and 
improvement. Companies acquire technologies from abroad, which in the first place allows for the development of the in-house manufacturing potential, its proliferation and increase of competitiveness, as well as interest in new markets. It leads to the development of new technology lines according to their own research, which undoubtedly leads to increased competitiveness (also with respect to technology) and export [Ciborowski, 2018, p. 43].

Technological conditions should be distinguished among many conditions for innovation diffusion (such as those related to demand, finances or regulation). Technological conditions refer to the company's technological potential which results from previously mastered technologies, as well as material resources and human resources [Firszt, 2012, p. 72]. Progress as an incremental process refers directly to the application of new solutions in specific conditions, therefore the technological advancement of previously used solutions is crucial. Investments allowing for the implementation of innovation are higher in the case of a lack of improving modifications. An analysis of such types of dependencies was conducted on the macroeconomic level, partially according to the Gerschenkron's hypothesis [1962]: the bigger is the difference in technological potential of respective countries, the faster the innovation diffusion process is. This process also depends on the absorption capacities of a specific entity (in this case it is the economy); such capacities include the initial technological potential and capacity to develop thanks to inhouse R\&D. The aforementioned dependencies may be extrapolated to activities conducted on the microeconomic scale, with a conclusion that the capacity to absorb innovation from the outside also to a large degree depends on the previous innovation activity of the specific company.

Absorption capacity, which is the capacity of an entity to recognise new external information, its acquisition and commercial application in the form of innovation is related to the knowledge and skills which already exist within the company [Jasiński et al., 2019, p. 160]. Companies (similarly to economies) have various initial technological potential, as well as their capacity to absorb innovation from external entities. Apart from factors such as the cost of innovation acquisition and adaptation, technical complexity, or the level of a company's preparation to use innovation, also the business intelligence is mentioned as a factor which has an impact on the capacity of a company to absorb innovation [Penc, 2007, p. 121]. Business intelligence consists of various elements including information, social, ecological, organisational, financial, technological, and also innovative intelligence. Innovative intelligence is manifested in a constant search for innovative solutions and acknowledging innovation as the principal element of the company's strategy. Organisations who have undertaken innovative activities in the past are able to adopt new solutions from external sources more effectively.

According to the results of analyses, the major barriers in the creation and implementation of innovative solutions in companies result mostly from the internal conditions, and to a less degree from the external conditions (related to their environment). They include [Radomska, 2015, pp. 79-80]: 
- low levels of knowledge concerning the potential innovative solutions and possibilities for their implementation;

- insufficient financial resources for investment in innovation and low levels of knowledge about the potential sources of acquiring resources;

- limited access to the sources of knowledge on innovation resulting from, for example, insufficient cooperation with entities creating innovations and supporting their implementation in companies (scientific centres and supporting institutions);

- insufficient interest of companies to invest and get involved in R\&D;

- mental barriers limiting the willingness to cooperate with various entities in the field of innovation (lack of trust to share knowledge with other entities);

- insufficient involvement of senior management and lower level staff with respect to innovative solutions;

- $\quad$ in the majority of companies, the lack of understanding on behalf of the management to promote a culture of innovation in the context of creating and implementing new solutions, and also of the use of the knowledge management in a company;

- focusing on the current operational activities, also lack of consolidation of innovation activities which are not subjected to the company's long-term strategy of operation.

Research on the conditions of an organisation's capacity to absorb also point to the company's resources of knowledge and experience, levels of investment in R\&D, skills of individual staff members to acquire external knowledge, and also an efficient system of communication within the organisation [Lis, 2018, p. 85].

Furthermore, the absorption capacity is influenced by the stage of development of a particular organisation, which includes: entrepreneurship (beginning), growth, maturity and decline or revival. The circumstances of the company's formation and its initial period of operation have a great impact on its further functioning. The maturity of an organisation may be described as a certain level of organisational skills which are the evidence of the organisation's readiness to fulfil tasks and achieve goals in a comprehensive way [Skrzypek, 2012, p. 401]. The characteristic features of this stage include obtaining financial resources, functional organisational structure, orientation towards strengthening the technology process and opening to innovation [Kozien, 2002, p. 117]. Starting from the uncertainty related to the operation of the company, through the repetitiveness of activities and acquisition of knowledge, an entity matures to the stage when the key aspect is the process of improvement and searching for new solutions [Martusewicz, Szumowski, 2018, p. 68].

Efficient implementation of innovations from external sources, and later their generation, requires the creation of an adequate organisational environment corresponding to the tasks which the company defines and to the conditions in which it operates. Therefore, it requires necessary competences in management and organisation, as well as management tools and techniques allowing for an efficient adjustment to changes taking place in the economic environment [Machnik-Słomka, 2018 , p. 408]. An enterprise in the stage of growth to maturity is capable to take on 
such challenges and to utilise the absorption potential to implement innovative solutions, and then to create them independently within the organisation.

Enterprises which undertake innovation activities appreciate benefits from the implemented innovative solutions related to the positive impact on the company's turnover, and thus on its financial results or the company's image. In the market, such entities are perceived as modern, dynamic, and development-oriented, and that also strengthens their competitiveness.

To recapitulate, it should be stressed that presented interdependencies create a feedback system. On the one hand, absorption of innovative solutions motivates the company to increase the innovative activities, thus achieving the competitive advantage. On the other hand, to benefit from $R \& D$ activities of competitors, the company needs to invest in the development of the absorption potential by undertaking its own activities in that respect. Therefore, in the process of innovation implementation, a company should involve its potential with respect to both absorption capacity and R\&D [Glabiszewski, 2016, p. 175, p. 177].

\section{Conclusions}

Innovation as the driving force of the economic development leads to the transfer of business activity from traditional dimensions to modern ones (which are described as intellectually intensive). As a result of human actions, knowledge which is the key factor of innovation - is generated, processed and distributed with the use of modern tools. Undoubtedly, that incurs changes of the economic structure, including the employment structure.

Diffusion of innovation is the source of the economic development, however, it does not secure the dynamics necessary to guarantee a fast achievement of the level characteristic for the developed countries. Therefore, it is crucial to identify factors which accelerate (or slow down) the diffusion process.

However, the key element is the transition from the development based on innovation diffusion to the generation of innovation thanks to endogenous factors. Therefore, it is indispensable to create internal absorption capacity, which later would be directed towards the development of innovative solutions.

In Poland, there is a tangible lack of mechanisms which would encourage entrepreneurs to increase the outlays for $\mathrm{R} \& \mathrm{D}$ or support innovation activities. Therefore, to raise the level of innovation at Polish companies, it is necessary to work out an efficient pro-innovation policy with adequate instruments supporting those entrepreneurs who search for and want to implement innovation [MazurWierzbicka, 2015, p. 108]. Nowadays, success of a company to a large degree depends on its inclination to innovative changes, since innovation becomes the indicator of development and market position. Innovation signifies intentionally implemented changes to generate a shift from the previous position to a new one, which is positively assessed by the company, and finally contributes to its business development and progress [Karpińska et al., 2017, p. 12]. 


\section{References}

Barańska-Fischer M., Blażlak R., 2016, Innowacyjność organizacji - istota zagadnienia, uwarunkowania $i$ charakter, [w:] Innowacje w biznesie. Wybrane zagadnienia, BarańskaFischer M., Blażlak R., Szymański G., Monografie Politechniki Łódzkiej, Łódź.

Chesbrough H.W., 2002, Graceful Exits and Foregone Opportunities: Xerox's Management of its Technology Spin-off Companies, „Business History Review”, vol. 76(4), pp. 803837, DOI: $10.2307 / 4127710$.

Ciborowski R., 2018, Determinanty międynarodowego transferu technologii (MTT) w krajach stabo rozwinietych, „International Business and Global Economy”, no. 37, pp. 4152, DOI: 10.4467/23539496IB.18.003.9376.

Ciborowski R., 2012, Modele rozwoju innowacyjnego, [w:] Ekonomika i zarzadzanie innowacjami w warunkach zrównoważonego rozwoju, Jasiński A.H., Ciborowski R. (red.), Wydawnictwo Uniwersytetu w Białymstoku, Białystok.

Driatalnośc innowacyjna pręedsiębiorstw w Polsce w latach 2013-2015, 2016, GUS, Warszawa. Driatalnośc innowacyjna przedsiębiorstw w Polsce w latach 2014-2016, 2017, GUS, Warszawa. Driatalnośc innowacyjna przedsiebiorstw w Polsce w latach 2015-2017, 2018, GUS, Warszawa. Driatalnośc innowacyjna przedsiębiorstw w Polsce w latach 2016-2018, 2019, GUS, Warszawa. European Innovation Scoreboard 2019, 2019, Publications Office of the European Union, Luksemburg.

Firszt D., 2012, Uwarunkowania dyfuzji innowacji w polskiej gospodarce, CeDeWu, Warszawa.

Firszt D., Jabłoński Ł., Woźniak M.G., 2013, Integrowanie rozwoju poprzez konwergencje realnq i technologicznq. Doświadczenia Polski i wnioski dla Ukrainy, „Nierówności społeczne a wzrost gospodarczy", nr 34, s. 7-24.

Gerschenkron A., 1962, Economic Backwardness in Historical Perspective, Harvard University Press, London.

Glabiszewski W., 2016, Potencjat absorpcyjny przedsiebiorstw finansowych w Polsce w procesie transferu innowacyjnych technologii, Wydawnictwo Naukowe Uniwersytetu Mikołaja Kopernika, Toruń.

Gwarda-Gruszczyńska E., 2017, Dyfuzja innowacji - nastęstwo komercjalizacji nowych technologii, „Organizacja i kierowanie”, nr 2(176), s. 383-396.

Jasiński A.H., Głodek P., Jurczyk-Bunkowska M., 2019, Organizacja i zarzqdzanie procesami innowacyjnymi, Polskie Wydawnictwo Ekonomiczne, Warszawa.

Karpińska K., Matel A., Protasiewicz A., 2017, Konsument w drialalności innowacyjnej przedsiebiorstw, PTE Oddział w Białymstoku, Białystok, DOI: 10.24136/eep.mon. 2017.1.

Kasperkiewicz W., 2009, Istota i charakterystyka innowacji, [w:] Innowacyjność, konkurencyjnośc i rynek pracy w procesie transformacji polskiej gospodarki, Kasperkiewicz W. (red.), Wydawnictwo Uniwersytetu Łódzkiego, Łódź.

Kozień E., 2002, Wybrane modele rozwoju organizacii, „Zeszyty Naukowe Akademii Ekonomicznej w Krakowie", nr 577, s. 109-118.

Kubielas S., 2009, Innowacje i luka technologiczna w gospodarce globalnej opartej na wiedży, Wydawnictwo Uniwersytetu Warszawskiego, Warszawa. 
Lis A., 2018, Rozwój badań naukowych w zakeresie zdolności absorpcyjnej organizacji, „Organizacja i Kierowanie", nr 3, s. 77-96.

Machnik-Słomka J., 2018, Znaczenie struktur organizacyjnych w innowacyjnym $i$ twórçym rozwoju przedsiębiorstw, „Zeszyty Naukowe. Organizacja i Zarządzanie”, z. 132, s. 407-417, DOI: 10.29119/1641-3466.2018.132.29.

Martusewicz J., Szumowski W., 2018, Modele dojrzałości a modele doskonatości. Niezależność czyy wspótzależność na drodze do rozwoju organizacji, „Organizacja i Kierowanie”, nr 1, s. 63-78.

Mazur-Wierzbicka E., 2015, Driałalnośc innowacyjna przedsiębiorstw w Polsce, „Zeszyty Naukowe Małopolskiej Wyższej Szkoły Ekonomicznej w Tarnowie”, nr 1(26), s. 97-109.

Niedzielski P., Rychlik K., 2007, Kreatywność a rozwój technologii informacyjnych - nowe obszary innowacyjności, „Zarządzanie Zasobami Ludzkimi”, nr 1, s. 21-31.

Oslo Manual: Guidelines for Collecting, Reporting and Using Data on Innovation, 2018, OECD, Paris-Luxembourg, DOI: 10.1787 /9789264304604-en.

Penc J., 2007, Zarzqdzanie innowacyjne. Sterowanie zmianami w procesie integracji europejskiej, WSSM, Łódź.

Podrecznik Frascati 2015. Zalecenia dotyczqce pozyskiwania i prezentowania danych z. zakresu driatalności badawczej i rozwojowej, Pomiar driatalności naukowo-technicznej i innowacyjnej, 2018, OECD Publishing, Paris/GUS, Warsaw, DOI: 10.1787/9788388718977pl.

Pomykalski A., 2001, Zarzqdzanie innowacjami, Wydawnictwo Naukowe PWN, Warszawa.

Radomska E., 2015, Innowacyjność jako wyzwanie rozwojowe - uwarunkowania dziatalności innowacyjnej przedsiębiorstw, „Kwartalnik Naukowy Uczelni Vistula”, nr 4(46), s. 63-85.

Rogers E.M., 2003, Diffusion of Innovations, Free Press, New York.

Skrzypek E., 2012, Wyznaczniki dojrzałości jakościowej w świetle wyników badań, „Prace Naukowe Uniwersytetu Ekonomicznego we Wrocławiu”, nr 264, s. 401-412.

Spychalska-Wojtkiewicz M., 2017, Uwarunkowania dyfuzji innowacji w sektorze MŚP, „Studia i Prace WNEIZ US”, nr 48/3, s. 33-44, DOI: 10.18276/sip.2017.48/3-03.

Rószkiewicz M., 2015, Wskaźniki innowacyjności gospodarek narodowych, [w:] Innowacje ocena w ujeciu mikro, mezo i makro, Kałowski A., Wysocki J. (red.), SGH, Warszawa.

The Global Competitiveness Report 2019, 2019, Schwab K. (ed.), World Economic Forum, Genewa.

The Global Innovation Index 2019. Creating Healthy Lives - The Future of Medical Innovation, 12th edition, 2019, Dutta S., Lanvin B., Wunsch-Vincent S. (Eds.), Cornell University, INSEAD, World Intellectual Property Organization, Ithaca, Fontainebleau, Geneva. 